DOI: https://doi.org/10.3126/njdrs.v18i01.41951

\title{
Sustainable Development Practices in Developing Countries: Major Drivers and Future Discourse
}

\author{
Umesh Acharya, PhD \\ Associate Professor at Central Department of Rural Development \\ Tribhuvan University, Nepal \\ Email: umesh.acharya@cdrd.tu.edu.np
}

\begin{abstract}
The objective of this article is to discuss the practices of sustainable development and its challenges in Nepal. Secondary data has been used such as library and documentation materials, and secondary information available. For the proper implementation of sustainable development corruption, free society is essential and the monitoring from people's side in the development programme is warranted. Publications of articles related to local governments and Journals published from different research institutes were used. The paper concludes that lack of proper human resources and utilization of natural resources in Nepal is not getting progress in for sustainable development. Nepal government should give emphasis on environment education and awareness programs should be organized in order to preserve natural resources. People's participation, equity and utilization of indigenous knowledge is vital for the development. At last civil society should have crucial role to control corruption. Active participation of local bodies and nongovernmental organization also can play vital role for its development with a coordination of ministry of environment and some international organizations.
\end{abstract}

Key words: Sustainable development, implementation, participation, monitoring, programme

\section{Introduction}

Sustainable development is the organizing principle for meeting human development goals while simultaneously sustaining the ability of natural systems to provide the natural resources and ecosystem services on which the economy and society depend. The desired result is a state of society where living conditions and resources are used to continue meeting human needs without undermining the integrity and stability of the natural system. Sustainable development can be defined as development that meets the needs of the present without compromising the ability of future generations to meet their own needs. Specifically, it is a way of organizing society so that it can exist in the long term. This means taking into account both the extremely present and those of the future, such as the preservation of the environment and natural resources or social and economic equity.

The "official" definition of sustainable development was developed for the first time in the Brundtl Report in 1987. The report, also known as Our Common Future, gave the most recognized and widely accepted definition of the term sustainable development in 1987. Following this report "the human ability to ensure that the current development meets the needs of the present without compromising the ability of future generations to meet their own needs" was the first widely accepted definition of sustainable development. The World Commission on the Environment and Development also stood out that sustainable development needed to consider that development has limitations.

According to the organization, the "present state of technology and the social organization on environmental resources together with the limited ability of the biosphere to absorb the effects of human activities" impose limitations on sustainable development. As a matter of fact, 'sustainable development' entered the global stage during the 1992 'Earth Summit' in Rio de Janeiro. The United Nations presented

Nepalese Journal of Development and Rural Studies, Volume, 18, 2021 
it as their strategic concept for shaping - and indeed saving - the future of the 'blue planet'. It promised to become the key-word for describing a new balance between the use and the preservation of nature's potential resources. The development of this concept can be traced further back. In 1980, the 'International Union for the Conservation of Nature', an association of nation states, environmental agencies and NGOs together with UNEP, the of the United Nations Environmental Programme, and the World Wildlife Fund, a non-governmental organization, published their 'World Conservation Strategy'. Under the patronage of the UN-General Secretary, this declaration was simultaneously presented in 34 capital cities around the world. Its title: "Living resource conservation for sustainable development." A few years before, in 1974, the term 'sustainable' had become a central issue in a document of another international organization. The aim of sustainable development is to balance our economic, environmental and social needs, allowing prosperity for now and future generations .Its focus is much broader than that. It's all about meeting the diverse needs of people in different communities, social cohesion, creating equal opportunity to ensure a strong and healthy society. Sustainable development also focuses on finding better ways of doing things without affecting the quality of our life.

The concept seems to have attracted the broad-based attention that other development concept lacked, and appears poised to remain the pervasive development paradigm for a long time (Scopelliti et al., 2018; Shepherd et al., 2016). The concept can be seen as a phrase consisting of two words, "sustainable" and "development." Just as each of the two words that combine to form the concept of Sustainable development able, that is, "sustainable" and "development", has been defined variously from various perspectives, the concept of Sustainable Development has also been looked at from various angles, leading to a plethora of definitions of the concept. Although definitions abound with respect to Sustainable development, the most often cited definition of the concept is the one proposed by the Brundtl \& Commission Report (Schaefer \& Crane, 2005).According to Pigou (1920), historically, Sustainable development as a concept, derives from economics as a discipline.

The discussion regarding whether the capacity of the Earth's limited natural resources would be able to continually support the existence of the increasing human population, it gained prominence with the Malthusian population theory in the early 1800s (Dixon and Fallon, 1989; Coomer, 1979). As far back as 1789 , Malthus postulated that human population tended to grow in a geometric proportion, while subsistence could grow in only an arithmetic proportion, and for that matter, population growth was likely to outstrip the capacity of the natural resources to support the needs of the increasing population (Rostow $\&$ Rostow, 1978). Therefore, if measures were not taken to check the rapid population growth rate having less energy or having less amount of natural resources would occur, resulting in misery for humans (Eblen \& Eblen, 1994). However, the import of this postulation tended to be ignored in the belief that technology could be developed to cancel such occurrence. With time, global concerns heightened about the non-renewability of some natural resources which threaten production and long-term economic growth resulting from environmental degradation and pollution (Paxton, 1993).

Different scholars of the world have said about the principles of sustainable development in different ways. Sustainable development has main key principle i.e. the conservation of the ecosystem. There is the need to conserve the ecosystem and biodiversity because without these, living organism will cease to exist. The limited means and resources on the earth cannot be enough for the unlimited needs of the people. Over-exploitation of the resources has negative effects on the environment and, therefore, for development to be sustainable, exploitation of the natural resources must be within the carrying capacity of the earth (Kanie \& Biermann, 2017). This means development activities must be carried out according to the capacity of the earth. That is why it is important, for instance, to have alternative sources of energy such as solar, instead of depending heavily on petroleum products and hydro-electricity (Molinoariet al., 2019).Wang (2016) suggest that proper human resource management is another important principle of sustainable development. It is the people who have to ensure that the principles are adopted and observed. It is people who have the responsibility to utilise and conserve the environment. It is people who have to ensure that there is peace. This makes the role of human resource in the research for Sustainable development critical. It is also argued that the process of Sustainable Development must be participatory in order to be successful and sustainable (Guo, 2017). The argument, which reminds the systems theory, 
is premised on the idea that Sustainable Development cannot happen through the efforts of only one person or organization. It is a collective responsibility which requires the participation of all people and appropriate entities. Sustainable is built on the principle of participation, which requires positive attitudes of the people so that meaningful progress can be achieved with responsibility and accountability for stability. The main objective of this paper is to describe the sustainable development practices and its challenges in Nepal.

\section{An Alternative Perspective}

Idea of sustainable development developed through alternative perspective and, therefore, the studies on sustainable development cannot be separated from the implementation of relevant policies. Sustainable development has comprised the subtle ideas and subsequently a series of sustainable development practices, such as developed by the United Nations Sustainable Development Summit. Sustainable development has evolved from not strictly distinguished discipline. Many changes have taken place as sustainable development and sustainability were tackling environmental issues to deal with the problem of declining economic growth. Based on the evolution of the sustainable development thoughts and formation of sustainable development theory by Lele (1991), Mebratu (1998), Shi et al. (2019) and other scholars. This paper reviews the evolution and development of sustainable theory in the early period (before 1972), the molding period (1972-1987) and the developing period since 1987 onward. In 1987, the World Commission on Environment and Development (WCED) drafted a report on human development, "Our Common Future", which the first time systematically defined sustainable development as the development that meets the needs of the present without compromising the ability of future generations to meet their needs".

The report focused on the global situation of the population, food, species and genetic resources, energy, industry, human habitation, etc. In addition, the report systematically discussed a series of major economic, social, and environmental issues faced by humanity and clearly proposed three viewpoints:1) the crisis of environmental, energy, and development cannot be separated; 2) the resources and energy on earth are insufficient for the needs of human development; and 3) current developmental models must be changed for the interests of present and future generations. These dentitions and viewpoints are highly general and concise but lack direct and practical agreeability. We can see that many more theories related to sustainable development were developed before 1987 and after 1987 many more. Although many more theories were applied on sustainable development but the main term "sustainable development" was implemented or verified in 1987.

\section{Methodology}

The study is based on secondary data. It has also used extensively the secondary information sources were used in this article. Publications of articles related to local governments, journals published of different research institutes were used.

\section{Discussions}

Sustainable development has its roots in ideas about sustainable forest management which were developed in Europe during the $17^{\text {th }}$ and $18^{\text {th }}$ centuries. In response to a growing awareness of the depletion of timber resources in England, John Evelyn(1662) argued that "sowing and planting of trees had to be regarded as a national duty of every landowner, in order to stop the destructive overexploitation of natural resources" in his 1662 essay Sylva. Lastly Sustainable development is development that meets the needs of the present without compromising the ability of future generations to meet their own needs. It contains within it two key concepts: The concept of 'needs', in particular, the essential needs of the world's poor, to which overriding priority should be given; and the idea of limitations imposed by the state of technology and social organization on the environment's ability to meet present and future needs.

Nepal is a very unique example of a developing country due to its culture, political practices and geopolitical location and not all development projects active in Nepal can be applied to many other developing countries, however, it helps in the illustration of how challenging sustainable development can 
be for many countries and how very important achieving it is. Hopefully, a dropping away of the corruption in the political system will make headway for positive change, nevertheless, owing to its longrunning roots in Nepal, that day will probably not arrive for many a year and sustainable development will have to continue to be led by citizen-led initiatives and NGOs. However, the following of the two faces its own internal problems and its own form of corruption (many foreign humanitarian workers come to Nepal for the easy money and not entirely out of purer aspirations) so it can prove to be inefficient. The future may not be bright for Nepal, nevertheless, there is a future in store for the country and it is up to the government, Nepali citizens and the international community to decide how it turn out. The Sustainable development have certain goals that have been well-integrated into Nepal's national development frameworks. Nepal has developed the Sustainable development Status and Roadmap 2016-2030, it needs Assessment, Costing and Financing Strategy, and its Localization Guidelines that spell out baselines, targets and implementation and financing strategies for each sustainable development goals. Necessary institutional set-ups are also in place for effective implementation.

The successful implementation of the Sustainable development goals relies on a country's own sustainable development policies, and governments have the primary responsibility for monitoring progress made at the national level. Citizens also play a key role to watch and support their governments' actions. In Nepal, the government prepared its first sustainable development goals country report, detailing and taking stock of its current development context, the starting line for the sustainable development goals. This report is expected to guide the work plan and implementation of the sustainable development goals in the coming years as Nepal aligns its periodic plans along with the 17 Goals and their targets. This made Nepal the first country in the world to publish its sustainable development goals country report and symbolizes Nepal's commitment and readiness to execute the sustainable development goals. The Constitution guarantees $33 \%$ of women representation in the national and provincial parliaments. Currently, women's representation in the local level governments is about $41 \%$. The gender parity index in enrollment for secondary level (Grades 9-12) set for 2019 has been achieved.

The sustainable development goals framework involves key systemic barriers to sustainable development, such as inequality, unsustainable consumption patterns, weak institutional capacity, and environmental degradation. Sustainable development goal is about achieving gender equality and empowering all women and girls. Nepal has made substantial progress in ensuring equal access to education, with gender parity in primary and secondary level school enrolment. But discrimination and violence against women and girls remains despite significant improvements. The proposed targets for 2030 include eliminating gender differences in all levels of education, wage discrimination at similar work, physical and sexual violence, and all harmful practices, and raising the presence of women in the national parliament and public service decision-making positions. Sustainable development has certain goals in Nepal. Reducing poverty and hunger, achieving universal primal education, ensuring gender equality, reducing child mortality, reducing maternal mortality, combat HIV aids, malaria and other diseases are the major indicators in measuring the development goals. They ensure environmental sustainability and develop a global partnership for development. The sustainable development agenda has been under global discussion for more than two decades. Nepal is implementing a number of social protection programmes including income generation for the poor, senior citizen allowances, pensions for retired employees, and free basic education and primary health care services.

The government has initiated various programmes targeting the poor, aged people, children, disabled people, socially excluded and marginalized. It is a phrase we hear thrown around from time to time in order to underline our ideal vision of the future - rid of all the problems that the inhabitants of the Earth tackle today. On the other side, many argue that the sustainable development goals cover too broad an area of issues and should be more focused if they are to be achieved over the next twelve years. Some targets could also be said to be rather idealistic. Politically, however, Nepal today is a progressive country, moving forward by the democratic mass movements of 1950, 1990 and 2006, heading in earnest towards building an inclusive state that is representative of its diverse people. The landmark constitution of 2015 plans a bold reshaping of statecraft and nationhood. It defines dozens of fundamental rights of citizens, and federates a unitary state into seven provinces for greater political and economic Nepalese Journal of Development and Rural Studies, Volume, 18, 2021 
inclusiveness. Nepal's fragile landscape is composed of snow and rock surfaces, pastures, forests, water bodies and very carefully maintained crop lands. While the beauty of the landscape itself is attractive for tourism and other forms of landscape marketing, it also contains rich biodiversity and sources of ecoservices. Protecting what is fragile, and harvesting sustainably, are essential to ensure that the landscape remains a source of prosperity for generations to come. Nepal in 2030 needs to achieve prosperity that is not only shared, but also lasting. This requires ensuring that economic growth be designed to go hand in hand with protecting and harnessing Nepal's natural resources and people's health, while investing sufficient resources into preparedness to address external and internal threats.

Though there are many goals related to sustainable development and it can be said that those goals are also difficult to get acquired. Developing countries like Nepal face different problems and challenges regarding sustainable development goals. Some problems like lack of good data, leader should pick their targets, local government often face complex challenges, population growth, etc. These were the major challenges faced during implementing of sustainable development in Nepal. Every fiscal year government announces newly and important works related to sustainable development but its works like building a castle in the air. The major problem is that every leader do corruption.

Not only Nepal but each developing country has same problems. Sustainable development should be implemented strongly especially for the landlocked countries like Nepal. For example we can say making highway roads. High amount of budgets are separated for constructing roads but works are done only for 20-30 percent and every year we heard the news like roads get destroyed by landslides or bridges get swept by floods. Mainly corruption should be ended in Nepal then only a good sustainable development is made in Nepal.

\section{Conclusion}

Sustainable development is one of the most important issues in the country like Nepal. Because of the soil erosion, land degradation and flood which are the main obstacles in the context of sustainable development in Nepal. Environment friendly is required for the sustainable development. Lack of proper human resources and utilization of natural resources Nepal is not getting progress in the sector of sustainable development. Nepal government should give emphasis on environment education and people awareness programs should be organized in order to preserve natural resources. People's participation, equity and utilization of indigenous knowledge is needed for its development. At last civil society should play in the against of corruption, active participation of local bodies and nongovernmental organization also can play vital role for its development with a coordination of ministry of environment and some international organizations like ICIMOD and IUCN.

\section{References}

Coomer, J. (1979). Quest for a sustainable society. Pergamon.

Dixon, J. A., \& Fallon, L. A. (1989). The concept of sustainability: Origins, extensions, and usefulness for policy. Society \& Natural Resources.

Eblen, R. A., \& Eblen, W. R. (1994). Encyclopedia of the environment.Houghton Mifflin Co.

John, E. (1664). Sylva, or adiscourse of forest-trees and the propagation of timbers. John Martin.

Kanie, N., \& Biermann, F. (2017). Governing through goals: Sustainable development goals as governance innovation. MIT Press Scholarship Online: January 2018, doi:10.7551/mitpress/9780262035620.001.0001

Lele, S.M. (1991). S.M. Sustainable development: A critical review. World Development 19 (6 (June 1991) 607-621.https://doi.org/10.1016/0305-750X(91)90197-P

Mebratu, D. (1998). Sustainability and sustainable development: Historical and conceptual review. Environ Impact Assess Review, 18(6) 493-520. https://doi.org/10.1016/S0195-9255(98)00019-5

Molinoari, E., Kruglanski, A. W., Bonaiuto, F., Bonnes, M., Cicero, L., Fornara, F., \& Degroot, W. (2019). Motivations to act for the protection of nature biodiversity and the environment: A matter of "Significance". Environment and Behaviour. Sage1-31. doi:10.1177/0013916518824376.

Nepalese Journal of Development and Rural Studies, Volume, 18, 2021 
Paxton, L. (1993). Environment facts 3: Sustainable development. Environmental Education Association of Southern Africa.

Pigou, A. (1920). The economics of welfare. Macmillan.

Rostow, W. W., \& Rostow, W. W. (1978). The world economy: History \&prospect (Vol. 1). University of Texas Press.

Schaefer, A., \& Crane, A. (2005). Addressing sustainability and consumption. Journal of Macromarketing, 22 (2): 170-181.

Scopelliti, M., Molinario, E., Bonaiuto, F., Bonnes, M.,Cicero, L.,De Dominicis, S., \& Bonaiuto, M.(2018).What makes you a "hero" for nature? Socio-psychologicalprofiling of leaders committed to nature and biodiversity protection across seven EU countries.Journal of Environmental Planning and $\quad$ Management. 993,doi:10.1080/09640568.2017.1421526

Shepherd,E.,Milner-Gulland,E. J.,Knight,A. T.,Ling,M. A.,Darrah,S.,Soesbergen,A., \&Burgess,N. D.(2016).Status and trends in global ecosystemservices and natural capital: Assessing progress toward Aichi Biodiversity. Conservation Letters, 9(6), 429-437. https://doi.org/10.1111/conl.12320

Shi, L., Han, L. Yang, F. \& Gao, L (2019). The evolution of sustainable development theory: Types, goals, and research prospects. Sustainability, 11(7158). doi:10.3390/su11247158

Nepalese Journal of Development and Rural Studies, Volume, 18, 2021 